Erica Etelvina Viana de JESUS ${ }^{1}$

Patrícia Oliveira Meira SANTOS $^{1}$

Marcus Vinicios Fóes

BARBOSA $^{1}$

Alexandre Moraes

PINHEIRO $^{1}$

Luis Fernando Pita

GONDIM $^{1}$

José Eugênio GUIMARÃES ${ }^{1}$

Maria Angela Ornelas de

ALMEIDA $^{1}$

\section{Correspondência para:}

MARIA ANGELA ORNELASDE ALMEIDA

Universidade Federal da Bahia-Escola de Medicina Veterinária

Av. Ademar de Barros, 500 - Ondina, Salvador, BA, Brasil

40170-110

aornelas@ufba.br

Recebido para publicação: 12/05/2003 Aprovado para publicação: 13/02/2006

\title{
Frequência de anticorpos anti-Neospora caninum em cães nos municípios de Salvador e Lauro de Freitas, Estado da Bahia - Brasil
}

\author{
1 - Escola de Medicina Veterinária - Universidade Federal da Bahia
}

\section{Resumo}

Palavras-chave:

Neospora caninum. Cães.

A freqüência de anticorpos IgG anti-Neospora caninum foi estudada em 415 amostras séricas de cães domiciliados e errantes, procedentes dos municípios baianos de Salvador e Lauro de Freitas, utilizando-se a técnica de imunofluorescência indireta, com ponto de corte igual a 1:50. Anticorpos da classe $\mathrm{IgG}$ anti-N. caninum foram detectados em $13,3 \%$ (22/165) dos cães domiciliados e em 11,2\% (28/250) dos errantes. As freqüências de soropositivos machos e fêmeas foram $8,0 \%$ (6/75) e 18,4\% (14/76) nos cães domiciliados e 12,6\% (17/135) e $9,6 \%(11 / 115)$ nos errantes, respectivamente. Não houve diferenças estatisticamente significativas entre sexo, idade, raça e a freqüência de soropositividade ao N. caninum dos cães domiciliados e errantes.

\section{Introdução}

A neosporose ocorre em cães jovens e adultos e se caracteriza por sinais neuromusculares de hiperextensão rígida, flacidez, atrofia muscular, paralisia progressiva do trem posterior, paralisia da mandíbula, dificuldade de deglutição e dermatites ${ }^{1}$.

O cão desempenha papel fundamental na epidemiologia da neosporose por ser o hospedeiro definitivo do Neospora caninum $^{2,3}$ juntamente com os coiotes ${ }^{4}$, nos quais se desenvolve a fase sexuada do ciclo com a produção de oocistos que são eliminados pelas fezes, sendo, portanto, um dos principais responsáveis pela disseminação do parasita nos diferentes ecossistemas, contribuindo para a infecção de animais domésticos e silvestres.

A ocorrência de anticorpos anti- $N$. caninum em cães já foi relatada em diversos países $^{5}$, mais recentemente em cães da área urbana, de fazendas de bovinos leiteiros e fazendas de ovinos e bovinos de corte da Nova Zelândia $(30,7 \%, 74,5 \% \text { e } 96,8 \%)^{5}$, em cães domiciliados ou de canis da Itália $(10,9 \%)^{6}$ e em cães da zona urbana e rural da Áustria $(2,1 \% \text { e 5,3\% })^{7}$. No Brasil, alguns estudos foram desenvolvidos, dentre os quais observam-se relatos em Minas Gerais $(6,7 \%)^{8}$, em cães domiciliados e errantes do Estado de São Paulo $(9,8 \% \text { e } 24,7 \%)^{9}$, em Rondônia $(6,7 \%)^{4}$, em cães da área urbana, periurbana e rural do município de Uberlândia em Minas Gerais (10,7\%, 19,9\% e $21,7 \%)^{10}$ e na Paraíba $(8,4 \%)^{11}$.

Considerando a distribuição cosmopolita do $N$. caninum, e a ocorrência de um caso fatal da doença em um cão na cidade de Salvador, do qual foi possível fazer o isolamento do parasito ${ }^{12}$, objetivou-se neste estudo determinar a soroprevalência do $N$. caninum em cães, criados nos municípios de Salvador e Lauro de Freitas.

\section{Materiais e Métodos}

\section{Caracterização dos Cães}

Dos 415 cães deste levantamento, 165 animais foram classificados como domiciliados, por serem procedentes de residências e canis particulares dos municípios de Salvador e Lauro de Freitas, tendo sido atendidos no Hospital de Medicina Veterinária da Universidade Federal da Bahia, e 250 como errantes, que foram provenientes das vias públicas da cidade de Salvador, capturados em dez distritos sanitários pelo Centro de Controle de Zoonoses, sendo as amostras sorológicas colhidas no período de 1994 a 2001. 
No grupo dos domiciliados, foram examinados 75 machos e 76 fêmeas com idade variando de 4 meses a 11 anos, não tendo sido registrado o sexo em 14 cães e a idade em 31 . Participaram deste levantamento cães das raças Pastor Alemão (58), Fila Brasileiro (31), Boxer (11), Rotweiller (10), Poodle (4), Mastif (4), Weimaraner (3), Cocker Spaniel (3), Dobermann (2), Dog Argentino (2), Labrador (2), Pitbull (2), Pointer (2), Fox Terrier (1), Beagle (1), Pastor Belga (1), Dog Alemão (1), Akita (1), Chow-Chow (1), sem raça definida (12), e em 13 cães não foi obtida a informação sobre a raça.

Dos cães errantes, todos sem raça definida, 135 eram machos e 115 fêmeas, procedentes dos distritos Barra/Rio Vermelho (28), Boca do Rio (10), Brotas (19), Cabula/ Beiru (31), Cajazeiras (17), Itapagipe (15), Itapuã (26), Pau da Lima (23), São Caetano/Valéria (26), Subúrbio Ferroviário (55).

\section{Reação de Imunofluorescência Indireta (IFI)}

As amostras de soro dos cães foram analisadas por IFI, para detecção de anticorpos IgG anti- $N$. caninum. Os dois grupos de cães, domiciliados e errantes, foram analisados em períodos distintos. No primeiro momento, utilizou-se como antígeno da reação de IFI taquizoítos do isolado JPA-1, para investigação sorológica dos cães domiciliados. Posteriormente, as amostras sorológicas dos cães errantes foram submetidas ao teste utilizando como antígeno a cepa Nc-Bahia, recentemente isolada e caracterizada ${ }^{14}$.

Os soros foram testados na concentração de 1:50, em solução tampão fosfato ( $\mathrm{pH} 7,2$ ), segundo metodologia descrita por Dubey et al. ${ }^{9}$. Foram consideradas positivas, as reações em que a fluorescência periférica total foi observada em mais de 50\% dos taquizoítos presentes.

Para determinação dos títulos de anticorpos, os soros foram submetidos a IFI nas diluições 1:50, 1:100, 1:200, 1:400, 1:800, $1: 1600$ e $1: 3200$.

\section{Analise estatística}

Os resultados obtidos foram associados com as variáveis sexo, idade, raça e procedência dos animais, pelo teste Qui-quadrado $(\mathrm{p}<0,05)$ utilizando o programa Primer of Biostatistic (versão 3.02, 1992).

\section{Resultados}

Dos soros analisados para detecção de anticorpos $\operatorname{IgG}$ anti-N. caninum foram observadas $12,1 \%(50 / 415)$ reações positivas, sendo 13,3\% (22/165) em cães domiciliados e $11,2 \%$ (28/250) em errantes, não havendo diferença estatisticamente significativa entre as variáveis sexo e tipo de criação (domiciliado e errante) (Tabela 1).

Também não foi observada uma diferença estatística significativa na freqüência de animais soropositivos segundo raça, faixa etária ou distrito sanitário de origem (Tabelas 2,3 e 4). Os títulos de anticorpos variaram entre 1:50 e 1:1600 (Tabela 5).

\section{Discussão}

A freqüência de anticorpos anti- $N$.

Tabela 1 - Freqüência de anticorpos IgG anti-Neospora caninum, detectados pela técnica de imunofluorescência indireta, em cães distribuídos segundo o sexo e tipo de criação nos municípios de Salvador e Lauro de Freitas, Estado da Bahia. Salvador, 2002

\begin{tabular}{|c|c|c|c|c|}
\hline \multirow{2}{*}{$\begin{array}{c}\text { Tipo de } \\
\text { criação } \\
\text { Sexo } \\
\end{array}$} & \multicolumn{2}{|c|}{ Cães domiciliados } & \multicolumn{2}{|c|}{ Cães errantes } \\
\hline & $\begin{array}{c}N^{\circ} \text { de } \\
\text { Amostras }\end{array}$ & Positivos $(\%)$ & $N^{\circ}$ de Amostras & Positivos (\%) \\
\hline Macho & 75 & $6(8,0)$ & 135 & $17(12,6)$ \\
\hline Fêmea & 76 & $14(18,4)$ & 115 & $11(9,6)$ \\
\hline Total & 151 & $20(13,3)$ & 250 & $28(11,2)$ \\
\hline
\end{tabular}


Tabela 2 - Freqüência de anticorpos IgG anti-Neospora caninum, pela técnica de imunofluorescência indireta, em cães domiciliados de diferentes raças, nos municípios de Salvador e Lauro de Freitas, Estado da Bahia. Salvador, 2002

\begin{tabular}{cccc}
\hline Raças & No amostras $^{\text {Positivas }}$ & Freqüência (\%) \\
\hline Pastor Alemão & 58 & 5 & 8,6 \\
Fila Brasileiro & 31 & 6 & 19,4 \\
Boxer & 11 & 3 & 27,3 \\
Rotweiller & 10 & 2 & 20,0 \\
Outras & 30 & 4 & 13,3 \\
Sem Raça Definida & 12 & 0 & 0 \\
Total & 151 & 20 & - \\
\hline
\end{tabular}

Tabela 3 - Freqüência de anticorpos lgG anti-Neospora caninum, pela técnica de imunofluorescência indireta, em cães domiciliados de diferentes idades, nos municípios de Salvador e Lauro de Freitas, Estado da Bahia. Salvador, 2002

\begin{tabular}{cccc}
\hline Faixa etária (anos) & $N^{0}$ amostras & Positivas & Freqüência (\%) \\
\hline$\leq 1$ & 28 & 2 & 7,1 \\
$1-2$ & 32 & 3 & 9,4 \\
$2-3$ & 28 & 8 & 28,6 \\
$3-4$ & 15 & 2 & 13,3 \\
$4-5$ & 12 & 0 & 0 \\
$>5$ & 19 & 2 & 0,5 \\
Total & 134 & 17 & - \\
\hline
\end{tabular}

Tabela 4 - Freqüência de anticorpos lgG anti-Neospora caninum, pela técnica de imunofluorescência indireta, em cães errantes da cidade de Salvador, em relação ao distrito sanitário de origem. Salvador, 2002

\begin{tabular}{cccc}
\hline Distrito Sanitário & $N^{\circ}$ de animais & $\mid \mathrm{FI} \geq 1: 50$ & Freqüência $(\%)$ \\
\hline Barra / Rio Vermelho & 28 & 1 & 3,6 \\
Boca do Rio & 10 & 2 & 20,0 \\
Brotas & 19 & 1 & 5,3 \\
Cabula/Beiru & 31 & 6 & 19,4 \\
Cajazeiras & 17 & 2 & 11,8 \\
Itapagipe & 15 & 0 & 0 \\
Itapuã & 26 & 3 & 11,5 \\
Pau da Lima & 23 & 2 & 8,7 \\
São Caetano Naléria & 26 & 6 & 23,1 \\
Subúrbio Ferroviário & 55 & 5 & 9,1 \\
Total & 250 & 28 & - \\
\hline
\end{tabular}


Tabela 5 - Freqüência de títulos de anticorpos lgG anti-Neospora caninum, detectados pela técnica de imunofluorescência indireta, em cães domiciliados e errantes nos municípios de Salvador e Lauro de Freitas, Estado da Bahia. Salvador, 2002.

\begin{tabular}{lcccccc}
\hline \multirow{2}{*}{ Tipo de criação } & \multicolumn{5}{c}{ Títulos de anticorpos } \\
\cline { 2 - 7 } Cães domiciliados & $1: 50$ & $1: 100$ & $1: 200$ & $1: 400$ & $1: 800$ & $1: 1600$ \\
\cline { 2 - 7 } & 10 & $5(22,7 \%)$ & $2(9,1 \%)$ & $2(9,1 \%)$ & $2(9,1 \%)$ & $1(4,5 \%)$ \\
Cães errantes & $(45,5 \%)$ & & & & & 0 \\
& 10 & 11 & $4(14,3 \%)$ & $1(3,6 \%)$ & $2(7,1 \%)$ & 0 \\
\hline
\end{tabular}

caninum de $12,1 \%$ em cães criados nos municípios de Salvador e Lauro de Freitas foram similares às observadas em estudos realizados na Itália ${ }^{6}$, em São Paulo (cães

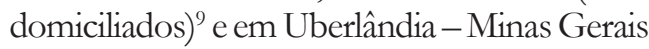
(cães da área urbana $)^{10}$, e superior às obtidas em cães urbanos e rurais na Áustria e em Minas Gerais, onde se encontrou, neste Estado, uma prevalência de $6 \%(11 / 163)$ em cães com alterações neuromusculares, respiratórias ou gastrintestinais ${ }^{8}$. Contudo, no Brasil foram observados dados de soroprevalência superiores em cães errantes de São Paulo9 e cães da zona periurbana e rural de Uberlândia ${ }^{10}$.

As diferenças nas prevalências observadas nos diversos locais podem ser atribuídas aos diferentes testes sorológicos e valores de ponto de corte utilizados. Neste estudo, a diluição de 1:50 na IFI foi escolhida seguindo a metodologia descrita por Dubey et $\mathrm{al}^{13}$, e que vem sendo adotada em muitos trabalhos, incluindo alguns realizados no Brasil $^{10,11,14}$. No entanto, alguns autores consideram como limiar de positividade neste teste a diluição de 1:2001, o que embora diminua a sensibilidade do teste, eleva sua especificidade, reduzindo a ocorrência de falso-positivos. A utilização de outros testes como o ELISA competitivo ${ }^{6}$ e o teste de aglutinação ${ }^{9}$, com pontos de corte diferenciados, também podem interferir na comparação dos resultados de soropositividade obtidos em diferentes estudos.

Soroprevalências distintas podem dever-se também a diferenças de exposição da população canina aos fatores de risco da doença. Diferentemente deste estudo, no qual se verificou similaridade na prevalência de anticorpos anti-N. caninum nos cães domiciliados e errantes, Gennari et al. ${ }^{9}$ demonstraram uma prevalência 2,5 vezes maior destes anticorpos em cães de rua quando comparado aos domiciliados, assim como Fernandes et al. ${ }^{10}$ observaram uma diferença na prevalência de cães de área urbana $(10,7 \%)$ e de área rural $(21,7 \%)$.

A possibilidade de transmissão horizontal entre cães errantes e rurais pode ser maior devido à facilidade de ingestão de roedores, pássaros e outros animais que podem servir como reservatórios do $N$. caninum e desta forma, funcionar como fonte de infecção para os cães. Alguns autores especulam que aves possam funcionar como vetores mecânicos de oocistos e que cães podem infectar-se pela ingestão destas aves ${ }^{15}$. Outro possível fator seria que cães errantes ou rurais seriam expostos mais freqüente à ambientes contaminados com oocistos eliminados por cães infectados. Por outro lado, a transmissão vertical e a conseqüente criação de animais assintomáticos podem ser responsáveis pela manutenção do nível de infecção por este coccídio nas populações caninas, o que poderia justificar a paridade entre os dados de soroprevalência encontrado nos cães domiciliados e errantes, no presente estudo.

Um outro aspecto relevante e que poderia ter influenciado esses resultados foram os dois diferentes isolados utilizados na preparação do antígeno, JPA-1 e NCBahia, para a análise das amostras de soro de cães domiciliados e errantes, respectivamente. Contudo, estudos de comparação antigênica entre isolados de $N$. caninum de diferentes 
países e obtidos a partir de bovinos ou caninos, evidenciaram não haver diferenças significativas no reconhecimento de soros controles na IFI ${ }^{16,17}$ e no padrão de proteínas identificadas por Western blotting ${ }^{18,19,20}$. Desta forma, parece não haver influência das características dos isolados sobre os ensaios sorológicos e embora estes autores apresentem discussões sobre outros isolados descritos na literatura, acredita-se que o mesmo possa ser aplicado para JPA-1 e NcBahia utilizados neste estudo.

Neste levantamento, não houve associação da soropositividade entre machos e fêmeas nas duas populações estudadas, concordando com estudos prévios que não indicaram a ocorrência preferencial da infecção a um determinado sexo ${ }^{7,10}$. Também não foi observada uma predisposição racial para a infecção pelo N. caninum, embora a maioria dos casos de neosporose clínica tenham sido descritos em Labrador Retrievers, Boxers, Greyhounds, Golden Retrievers e Basset Hounds $^{1,21}$. Este último fato, deve-se principalmente a maioria dos estudos ocorrerem em países do hemisfério Norte, onde essas raças são mais difundidas e não há ocorrência significativa de cães SRD.

\title{
Frequency of antibodies anti-Neospora caninum on dogs from Salvador and Lauro de Freitas, Bahia state - Brasil
}

\begin{abstract}
The frequency of anti-Neospora caninum IgG antibodies was studied in 415 serum samples from owned and stray dogs from Salvador and Lauro de Freitas counties. The Indirect immunofluorescence was performed using a cut-off of 1:50. Anti- $N$. caninum $\operatorname{IgG}$ antibodies were detected in $13.3 \%(22 / 165)$ owned dogs and in $11.2 \%(28 / 250)$ stray dogs. The frequencies of males and females seropositivity were $8.0 \%(6 / 75)$ and $18.4 \%(14 / 76)$ for owned dogs and $12.6 \%(17 /$ $135)$ and $9.6 \%(11 / 115)$ in the stray dogs population, respectively. There were not a statistical significant difference between sex, age, breed and the dogs anti- $N$. caninum IgG antibodies incidence.
\end{abstract}

Key-words: Neospora caninum. Dogs.

IFI.

\section{Referências}

1 DUBEY, J. P.; LINDSAY, D. S. A review of Neospora caninum and neosporosis. Veterinary Parasitology, v. 67, n. 1/2, p. 1-59, 1996.

2 LINDSAY, D. S.; DUBEY, J. P.; DUNCAN, R. B. Confirmation that the dog is a definitive host for Neospora caninum. Veterinary Parasitology, v. 82, n. 4, p. 327-333, 1999.

3 McALLISTER, M. M.; et al. Dogs are the definitive hosts of Neospora caninum. International Journal for Parasitology, v. 28, n. 9, p. 1473-1478, 1998.

4 GONDIM, L. F.; et al. Coyotes (Canis latrans) are definitive hosts of Neospora caninum. International Journal for Parasitology, v. 34, n. 2, p. 159-161, 2004.

5 ANTONY, A.; WILLIAMSON, N. B. Prevalence of antibodies to Neospora caninum in dogs of rural or urban origin in central New Zealand. New Zealand Veterinary Journal, v. 51, n. 5, p. 232-237, 2003.

6 CAPELLI, G.; et al. Sero-epidemiological survey of Neospora caninum infection in dogs in north-eastern
Italy. Veterinary Parasitology, v. 123, n. 3-4, p. 143148, 2004.

7 WANHA, K.et al. Prevalence of antibodies against Neospora caninum and Toxoplasma gondii in dogs and foxes in Austria. Veterinary Parasitology, v. 128, n. 3-4, p. 189-193, 2005.

8 MINEO, T. W. et al. Detection of IgG antibodies to Neospora caninum and Toxoplasma gondii in dogs examined in a veterinary hospital from Brazil. Veterinary Parasitology, v. 98, n. 4, p. 239-245, 2001.

9 GENNARI, S. M.; et al. Occurrence of Neospora caninum antibodies in sera from dogs of the city of São Paulo, Brazil. Veterinary Parasitology, v. 106, n. 2, p. 177-179, 2002.

10 FERNANDES, B. C.; et al. Prevalence of antiNeospora caninum antibodies in dogs from urban, periurban and rural areas of the city of Uberlandia, Minas Gerais - Brazil. Veterinary Parasitology, v. 123, n. 1-2, p. 33-40, 2004.

11 AZEVEDO, S. S.; et al.. Seroepidemiology of Toxoplasma gondii and Neospora caninum in dogs from the state of Paraiba, Northeast region of Brazil. Research 
in Veterinary Science, v. 79, n. 1, p. 51-56, 2005.

12 GONDIM, L. F.; et al. Isolation of Neospora caninum from the brain of a naturally infected dog, and production of encysted bradyzoites in gerbils. Veterinary Parasitology, v. 101, n. 1, p. 1-7, 2001.

13 DUBEY, J. P.; et al. Neonatal Neospora caninum infection in dogs: Isolation of the causative agent and experimental transmission. Journal of the American Veterinary Medical Association, v. 193, n. 10, p. 1259 1263, 1988.

14 CANON-FRANCO, et al. Prevalence of antibodies to Neospora caninum in dogs from Amazon, Brazil. Veterinary Parasitology, v. 115, n. 1, p. 71-74, 2003.

15 HEMPHILL, A.; GOTTSTEIN, B. A European perspective on Neospora caninum. International Journal for Parasitology, v. 30, n. 8, p. 877-924, 2000.

16 CONRAD, P. A.; et. al. In vitro isolation and characterization of a Neospora sp. from aborted bovine foetuses. Parasitology, v. 106, n. 3, p. 239-249, 1993.

$17 \mathrm{KIM}$, J.; et al. In vitro isolation and characterization of bovine Neospora caninum in Korea. Veterinary Parasitology, v. 90, n. 1-2, p. 147-154, 2000.

18 BARBER, J. S.; et al. Characterization of the first European isolate of Neospora caninum (Dubey, Carpenter, Speer, Topper and Uggla). Parasitology, v. 111 , n. 5, p. 563-568, 1995.

19 DUBEY, J. P.; et al. Canine neosporosis: clinical sings, diagnosis, treatment and isolation of Neospora caninum in mice and cell culture. International Journal for Parasitology, v. 28, n. 8, p. 1293-1304, 1998.

20 STENLUND, S.et al. Characterization of a Swedish bovine isolate of Neospora caninum. Parasitology Research, v. 83, n. 3, p. 214-219, 1997.

21 CHEADLE, M. A.; LINDSAY, D. S.; BLAGBURN, B. L. Prevalence of antibodies to Neospora caninum in dogs. Veterinary Parasitology, v. 85, n. 4, p. 325-330, 1999. 